CHAPTER 4

\title{
Guy Debord, a Critique of Modernism and Fordism: What Lessons for Today?
}

\author{
Olivier Frayssé
}

\section{Introduction}

The advent of the Age of the Internet seems to have vindicated Debord's approach to the life vs the spectacle issue. The multiplication of screens even suggests a mise en abyme of the concept as we spend an increasing part of our lives watching merchandise such as smartphones that showcase the world as merchandise, from news to pornography and all sorts of consumer goods and services, and the omnipresent reality of the virtual expresses itself as in 'second life' or 'virtual reality' devices, and Pokemon Go. While, as Christian Fuchs (2015) has shown, the Internet has brought commodity fetishism to unprecedented heights by obfuscating labour processes and class relations further than anything capitalism had done before, Debord's writings pay more attention to the manner in which the labour processes and class relations are hidden than to the realities of these labour processes and class relations, which makes it difficult to use his findings to analyse the changes in labour processes and class relations that have occurred since his death, which coincided with the dawn of the digital age.

To embark on this mission is thus challenging. To begin with, like so many other things, both the Internet and Debord's concepts need to be reterritorialized

How to cite this book chapter:

Frayssé, O. 2017. Guy Debord, a Critique of Modernism and Fordism: What Lessons for Today? In: Briziarelli, M. and Armano, E. (eds.). The Spectacle 2.0: Reading Debord in the Context of Digital Capitalism. Pp. 67-80. London: University of Westminster Press. DOI: https://doi.org/10.16997/book11.d. License: CC-BY-NC-ND 4.0 
and historicized. Indeed, his book La Société du Spectacle was obviously written under the dual sign of the West (US)/East (Soviet Union) dichotomy, including the original distinction between the 'spectaculaire diffus' and the 'spectaculaire concentré on the one hand and the impact of the US 1960s movements and theories on the other hand. His films, notably La Société du Spectacle are replete with American references in more than one way, interspersed with French references establishing the depth of US influence, and in this aspect not unlike Gramsci's famous 'Americanismo e Fordismo' entry in his Prison Notebooks (Gramsci 1977), that Debord apparently never mentioned. Neither writer had first-hand knowledge of the United States, where they never set foot (and Debord took pride in his ignorance of English), and both, maybe for that reason, had an innovative approach to the type of model that was coming from the US to Europe at that time.

What this paper will explore then is the relevance and originality of Debord's take on the pre-Internet age, with a focus on the importance of Debord's knowledge of and interest in the United States. Was the spectacle concept pertinent? Is the advent of the Age of the Internet a development of the 'spectacle society'? And, more crucially, does it help us understand the labour regimes of digital workers? We must obviously start with a critical examination of Debord's theories, but that again poses a series of challenges.

The first challenge lies in the exceptional intertwining of Debord's personal life and his productions. An enthusiast of life being there to be lived, Debord was also a charismatic leader preaching by spectacular example and, while he wrote relatively little on paper or screen, he was a relentless autobiographer (from the ironic Mémoires collage to Panégyrique or Cette Mauvaise Réputation, and his numerous interventions to edit his public image). He seldom hid his self behind his pronouncements (although they served to conceal as well), so that the biographical dimension cannot be avoided, lest we miss the praxis that brought him to theorize. Three Debord biographies are worth mentioning: the hagiographic intellectual biography published by Anselm Jappe in 1993, Guy Debord, which Debord himself praised; Christophe Bourseiller's Vie et mort de Guy Debord, in 1999, well-researched, striving for nuance and objectivity; written by a connoisseur of French radicals and France who is not a great theoretician, it is very reliable when it comes to facts and context. And finally, Jean-Marie Apostolidès' Debord: le naufrageur, 2015, a thoroughly hostile and well-researched scholarly production based on an extensive study of archives.

\section{Debord's Theories as Countercultural Productions}

One way to look at Debord's theoretical productions is to historicize them, and consider them as products of a countercultural community to which he belonged, and in which he played a major role as theoretician. Debord was the main theoretical force behind anti-Isou Letterism and the Situationist International, and 
the main reason why he is remembered and studied is his theories, essentially his use of the notion of spectacle to name and explain the then-existing mode of capitalist domination. Debord's preoccupations have evolved over time, but two traits have remained from beginning to end: a theoretical bent, and the exaltation of praxis. His theories were inseparable from praxis, they were explicitly a theorization and rationalization of his praxis. In his Commentaires sur la Société du Spectacle of 1988, he presented his 1967 La Société du Spectacle book as the last step in a process of critical thinking and revolutionary practice, published at the culminating point of the Situationist International, to serve future subversive forces (Debord, 1992b, 85). Earlier, his discovery of Letterists in Cannes had led him to move to Paris, share their lifestyle, which included hours of 'critical thinking' and talking against everything and everybody outside the group, long before he provided this polemical praxis with something that resembled a theoretical basis. He brutally broke relations with associates long before he formalized exclusion as a cornerstone of the Letterist or Situationist Internationals principles (Bourseiller, 143-144). Debord very likely fantasized sleeping with his half-sister before developing a justification of incest as revolutionary and therefore something to be recommended to the members of his group (Apostolidès 2015a, 202-204, 749-750). He also developed the 'marsupial' theory (Apostolidès 2015312 seq.) concerning girls, an uncomfortably pressurizing sort of rationale to be used for seduction. Picturing himself as essentially a destroyer, he was to make the Hegelian notion of the negative a central feature of his thinking, the Art of War his lifelong game, and his polemical approach a trademark. A lot of this was also designed to protect - it could be argued - what non-devotees might describe as an indulgent lifestyle, always comfortable and sometimes verging on the luxurious based on greed, sloth, sexual license and even a little violence when it came to power and status (Bourseiller, 136, 207, Apostolidès 2015a, 343), altogether a brilliant rationalizing of a condition now described as perverse narcissism by psychologists.

An attempt at living apart from 'mainstream' culture as a group characterizes voluntary subcultures, which can be more or less tolerated by society and the state, which allocate each subculture its space. When one of these subcultures presents itself as an alternative to the dominant culture for all, and not just the original group members, as an alternative way of life, when it presents a coherent challenge to the dominant culture, the word counterculture, coined by Theodore Roszak (Roszak 1968), is apposite. Debord's theoretical productions were a rationalizing and universalizing of the practices, values and beliefs of what Alice Becker-Ho finally defined as a kind of Gipsy king (Apostolidès, 490-493), holding court for several generations of Bohemians. In the 1960s, there was a simultaneous rise of countercultures in several countries in the West, which resonated with the aspirations of the youth to change the world they were inheriting, and which later influenced the youth in Eastern Europe.

The US and France were the two countries where the youth movement, and the accompanying subcultures and countercultures climaxed at the same time, 
in 1968, while interacting with similar explosions all over the developed world. The situation in the two countries was remarkably similar and completely different. In both countries, the countercultural element emerged in the 1950s (Existentialism, Letterism, the Beat Generation) and reconnected critically with pre-World War II oppositions to both capitalism and Stalinism in politics and art (Trotskyism, anarchism, Dadaism, surrealism). In both countries, the countercultures rubbed shoulders with social movements, which to them were evidence that they were right in rebelling against the status quo, and interacted with them to some extent. The differences were quite striking as well, and not only in terms of social makeup, size and degree of centralization, power, or national culture of the two countries. In the US, the 'civil rights' revolution lasted throughout the 1960s, and so did the Vietnam War. The 'Movement' of the youth against imperialism at home and abroad was a real force in the country for several years, generating a measure of democracy. In France, imperialism was defeated as early as 1962 with the independence of Algeria, and the undertaker of the French Empire, De Gaulle, de-democratized the institutions.

As a consequence, France and France's youth looked tranquil until the 'explosion' of 1968, which came as a surprise for almost everyone. The youth movement had developed alongside movements within the 'traditional' organizations of the Left during the Algerian war (1954-1962), and did so with little interest in the French counterculture expressed by Existentialists, Letterists and later Situationists; the youth movements then combated Gaullism after 1962 within the same traditional Left organizations and their radical offshoots (including Socialisme ou Barbarie, an organization that Debord joined briefly, and where he did both theoretical work and legwork for a few months), and their influence only picked up speed in 1966, largely in solidarity with the American movement, the unifying theme in France being Vietnam and the civil rights revolution. Some American countercultural themes were also imported, such as sexual liberation. The handful of Situationists, who were genuinely countercultural and revolutionary came out of their practical Parisian isolation by taking over the student organization in Strasbourg in 1966, and also played a significant role in Nantes; they thus had some political impact between 1966 and May 1968, but were just one of many groups, admittedly the one that delivered the biggest bang for the smallest buck and the one which supposedly best represented the 'spirit of May' in the French youth, far beyond the student body (Bourseiller, 440-493; 549-599). The lid put by De Gaulle on expression, sexuality and rebelliousness was blown off and the whole country, freed by the general strike, faced quite a 'situation'.

Debord and the Situationists could feel vindicated in that their immediate liberation mottos were lived up to by many, and also by their understanding that this spontaneous response showed that they had correctly identified the major problem with society. Their very minor role in the events of 1968 left them a small place in history, but their capture of the 'spirit of 68', soon recycled by capitalism, made them icons of the French 70s counterculture, a role Debord 
did not care for, hence his dissolution of the so-called Situationist International and his scorn for the 'pro-Situs' that emerged.

\section{The Genesis of Debord's Theories}

It is not without significance that Debord started (and ended) with an aesthetic criticism of capitalism and the society of his times. His rebellion was against falseness, lack of authenticity, the humdrum quality of everything, or rather the lack of quality of almost everything. He lived up to the demands of this rebellious spirit at huge personal costs of self-discipline, with the constant support of psychotropic substances, and principally a methodical, lifelong use of alcohol (for which he substituted tomato juice during the months when he put $\mathrm{La}$ Société $d u$ Spectacle together), which led him to a premature death by suicide. Boredom and slumber were the great enemies of life, and there was no way of defeating them unless one always kept on edge, on the edge, on the fringes and on top of the game.

The pursuit of 'happiness' as a succession of exalted moments was the mission. The motto was to be synthesized as 'jouir sans entraves', without fetters, which the Situationists proclaimed as a program for May 1968 on the walls of Paris, jouir meaning both to enjoy and to have an orgasm in French. This was the exact opposite of the model of everyday 'happiness' through consumption of commodities that reigned supreme everywhere, a US import that had started glutting the French market under the Marshall plan in the 1950s, which also flooded French screens with the Hollywood movies that were to shape Debord's cinematic sensibilities and provide the mine from which most of his cinematographic détournements would come.

The way I reconstruct the genesis of Debord's theorizing is by asking three questions that he must have faced, since he answered them. First, what kind of theory can fit a life project that gratifies Debord as an individual and still be a theory, something that has a universal value while remaining valid for this particular, idiotic self? What social group can make it its own and give it a universal dimension though a collective practical activity? Where are the materials to construct one?

The answer to the first question is in the style, aphoristic, surgical, deliberately misleading and demanding a form of subsumption under Debord's unique personality. What is the spectacle? The spectacle is this, but it is also this, and that, and something else too, you idiot, just read my lips, watch my moves, enjoy being tricked. Debord was always the Juggler, or Magician from the Tarot that he used to illustrate his last production (Debord 1998). The answer to the second question is twofold: in reality, successively, the groups that Debord aggregated around himself, the intellectuals that he fascinated, the generations of rebels that found inspiration in his works and his image, and the academics that discuss him; in fiction, the proletariat, because, under the conditions of 
'state monopoly capital' (the then dominant concept in the French communist and radical circles, not referred to but described in SS 87) associated with the society of the spectacle, the bourgeoisie has renounced 'all historical life apart from what has been reduced to the economic history of things'.

Debord shares the Marxist and anarchistic visions of the proletariat as the negative of capitalism, and therefore its future death, but, contrary to Marx's revolutionary predictions based on the growing concentration and pauperization of the proletariat, he never gives any objective reason why the proletariat should be in a position to become a successful 'pretender to historical life', and, since it is the only one, the prospects are rather gloomy, unless one finds a way to shake them out of their spectacle-induced torpor, disgust them from their hard-earned possessions, whose characteristics as values in use Debord negated, and of course demand an immediate end to their labour. Debord seemed to fantasize the proletariat. He saw in the Watts riots of 1965 a rejection of the society of the spectacle by African-American proletarians, on the grounds that the rioters, being precisely those who were excluded from the 'superopulence' and Hollywood on account of their race, could but practically negate the commodity as something one has to pay for while (mistakenly) demanding that the spectacle society should fulfil its promises of affluence for all, and affirming their will to live the real life in the process (Debord, 1965). For Debord, a parasitic upstart in the intelligentsia posing as déclassé from the bourgeoisie, the proletariat was never anything but a mythical construction empowering him to pass judgment in His name, a convenient God that never cared to realize His essence, since it never succeeded in establishing its reign on earth through the workers' councils, while giving signs and miracles in the Paris Commune, the Spanish Civil War, the Hungarian revolutions, and so on, and therefore left its various prophets to rule their churches with an iron hand while warring with rival prophets. He was probably not the worst of his kind.

The answer to the third question is probably the more interesting. Debord was an avid and eclectic reader, a self-taught man free from the teachings of the School or the Party(ies), from any form of reverence for existing luminaries, alive or dead, and with a distinct preference for the dead, especially those without posterity (as shown by his editorial work on Baltasar Gracián and others). La Société du Spectacle uses a wide array of concepts borrowed, with or without acknowledgment, from a host of thinkers ranging from the Hegel-FeuerbachMarx-Lukács lineage to contemporary American sociology, Boorstin, Whyte, Riesman: anything except contemporary French thinkers, who were not to be dignified in a theoretical book, where insults did not fit, all the more so since he owed so much to them, especially Henri Lefevbre. All those he quotes or subverts through détournement had grasped part of the totality, but Debord synthesizes them by surpassing them, refuting them in part, diverting them playfully, and fundamentally killing them. For Debord was the parricidal parasite. Just as he lived as a parasite of society, off his family (far from poor, although he suggests the opposite in Panégyrique), his wives and friends, he lived off 
the thought of others and phantasmatically killed them in the process. 'You, young man, do not despair; for the vampire, contrary to what you think, is your friend. And if you count Sarcoptes, who produces scabies, you will have two friends', as Lautréamont, whom Debord never stopped reading, concluded the first chant of Maldoror (Lautréamont 1938, vol. 1 256).

If parasitism is the form, eclecticism is the substance. To produce a theory, one has to be a poet, one involved in poiesis, not just praxis, and why not through collage? Collage is an effort at synthesis of a fragmented reality by exposure of the fragmentation. The collage tradition, born with Dada, taken up by the surrealists, re-emerged on both sides of the Atlantic in the 1950s with Burroughs and the Letterists, and the best platform for collage was the cinema, since the crucial part of the production process, editing, consisted of gluing together pieces of film. And since the cinema was the original art of the spectacle society, hiding the process of its creation behind the smooth and slick flicks narratives, the only proper use of the cinema was 'anti-cinema', unveiling the truth of the cinematic process as an antidote to the society of the spectacle, in a Brechtian manner.

'Thou shall never work', wrote Debord on the walls of Paris in 1953, but that meant 'thou shall never engage in wage-work'. Collage is hard work, just like parasitism, but it also involves a real production. While the parasitism of society is akin to that of predators, slowly destroying what they parasitise hence the lifelong fascination of Debord for the 'dangerous classes' described by Chevalier (Chevalier 1958), that is, criminals - the parasitism of intellectual productions is more like that of saprophytes, the vegetable organisms that live off decaying matter, provided the matter has been killed or has died, and it can even be a symbiotic relationship, when the guest organism prolongs the life of the host in a modified form, which Debord did with the Hegelian-Marxist tradition.

\section{The Society of the Spectacle, a Critique of High Modernism}

Let us now take on the central concept of spectacle. The spectacle is a materialized Weltanschauung (SS 5) that has made reality recede into it (SS 1), creating from an abstracted part of reality a separate pseudo-world (images detached from life and merged into a stream) that provides an object that can only be contemplated and provides a unified and illusory reality: 'The spectacle is a concrete inversion of life, an autonomous movement of the nonliving' (SS 2), 'a visible negation of life - a negation that has taken on a visible form' (SS 10). The spectacle is visible in 'particular manifestations-news, propaganda, advertising, entertainment' (SS 6), and 'presents itself simultaneously as society itself, as a part of society, and as a means of unification' (SS 3): it is at the same time a 'model' for society (SS 6), a separate sector that is 'the focal point of all vision and all consciousness' (SS 3), and it also 'serves as a total justification of the 
conditions and goals of the existing system' (SS 4): thus it is the material form of ideology (SS 212), it is even ideology par excellence, since the 'essence' of ideology is 'the impoverishment, enslavement and negation of real life' (SS 215). At the same time, it is a 'social relation between people that is mediated by images' (SS 4); this social relation is rooted in the mode of production since the spectacle is 'the omnipresent affirmation of the choices that have already been made in the sphere of production and in the consumption implied by that production', and the spectacle is both the 'result and the project' of this mode of production (SS 6).

\section{High Modernism and High Fordism}

What is this mode of production? It is capitalism, of course, whether state monopoly capital in the West or in the East, but the word appears very late in the book (SS 56). The spectacle is a stage of capitalism: 'it is the stage at which the commodity has succeeded in totally colonizing social life' (SS 42). The central concept is not capitalism, but 'the economy'. What about 'the economy'? First and foremost, it is that of developed countries, characterized by 'abundance. The development of the world market makes it universal, since, 'although this qualitative change has as yet taken place only partially in a few local areas, it is already implicit at the universal level that was the commodity's original standard, a standard that the commodity has lived up to' (SS 39), and 'in the less industrialized regions, its reign is already manifested by the presence of a few star commodities and by the imperialist domination imposed by the more industrially advanced regions' (SS 42). But 'the abundance of commodities-that is, the abundance of commodity relations - amounts to nothing more than an augmented survival' (SS 40), since no one can understand or live the totality of the real world.

What Debord is denouncing there in his own language is what the US counterculture had labelled the consumer society. The labour regime he describes is high Fordism: subject to rigorous disciplines at work, the worker turned consumer in his leisure time is now the subject of the full attention of the specialists of domination: 'At this point the humanism of the commodity takes charge of the worker's 'leisure and humanity' simply because political economy now can and must dominate those spheres as political economy' (SS 43). Since survival is now guaranteed in the industrialized countries, the answer to the perennial question 'how to make the poor work' (Debord, 1992a, 6) includes the necessity of both making them consume commodities equated with goods and consume their leisure time in the spectacle, since it 'monopolizes the majority of the time spent outside the production process', (SSSS 6), away from any will to change the system, as 'the spectacle is a permanent opium war designed to force people to equate goods with commodities and to equate satisfaction with a survival that expands according to its own laws. Consumable survival must constantly expand because it never ceases to include privation', since pseudo-needs are 
constantly manufactured (SS 44), while desire is asphyxiated. The economic regime he describes is that of mass production and mass consumption, the 'virtuous' cycle of Fordism and Keynesianism. All these elements of critique were present in the US counterculture, this is what brought Allan Ginsberg to 'Howls' in favour of America three years after Debord's Howls in Favour of Sade, his first film.

The reason why Debord is remembered and his book was named the Society of the Spectacle is that he added to the understanding of Fordism in its economic, political and social dimensions an understanding of the specific form of ideological domination (in Gramsci's sense) that Fordism used: the spectacle of the commodity. The importance of images in modern life had been observed by Daniel Boorstin, whom Debord credits with describing in The Image 'the way the American spectacle was consumed as a commodity' (SS 198). The French translation, by Janine Claude, of what was originally called The Image, or What Happened to the American Dream, was published in 1963 by Julliard (Boorstin, 1963), and probably clarified Debord's concept of the spectacle, which he started using in 1960 (Apostolidès 2015, 233), from his understanding of the theatre, notably through Boorstin's use of the word spectacular, while Debord's analysis of the mechanism of capitalist manipulation came from his reading of Vance Packard (Apostolidès 2015, 236). The importance of images of commodities in modern life, starting with the Arcades in Paris had been noticed by Walter Benjamin, whom Debord must also have read. Debord also mentions American sociologists Whyte and Riesman, who had reflected on the changes in American society that had resulted from Fordism. Fordism, both on the production and consumption sides appeared as quintessentially American to Debord, as they had to Gramsci, and its consequences for other societies appeared as the 'Americanization of the world' (Debord 1992, 12). That Debord was essentially discussing Fordism is what Gianfranco Sanguinetti, in his Debordian dismissal of Apostolidès (Sanguinetti 2015) says when he ranks the Société du Spectacle, together with Huxley's Brave New World and Orwell's 1984 as one of the three important books of the twentieth century.

\section{What Use is Debord in Understanding Digital Work and Labour in the Age of the Internet?}

When trying to address the issue of the possible uses of Debord to analyse the situation of knowledge workers in the Age of the Internet and the place of their labour, one is confronted with several difficulties. First, the computer was to Debord a mere extension of the impersonality of the machine, its workings a continuation of the procedural regime of Fordism. Second, and most problematic, he never dealt with the issues of work and labour because he was never in any way interested in them. He had no sense of shame in consuming endlessly the product of the labour of others, and produced a general critique 
of the alienation of everyone (except Debord), regardless of class, and never one of exploitation, which would have carried the unthinkable stigma of what he would have called bourgeois, or religious, morality. Debord never cared for actual workers in any way: their living and working conditions, their efforts to better their condition, their efforts to challenge capitalism, their strikes (he went through the great strikes of 1953 in France, that paralyzed the country, writing about strikes ... in Spain), what actually happened in the factories in 1968, none of this ever meant anything to him. When he was involved in a productive enterprise, such as making a film, he played only the demanding and inefficient manager's part and his employees ended up bitter, rejected and sceptical about his abilities (Apostolidès 2015, 395). Work and labour are the blind spots in Debord's work. He never cared for the real processes of alienation and exploitation within the capitalist wage system under Fordism or before, satisfying himself with the general knowledge of the notion of commodity fetishism, thereby turning the concept of commodity fetishism itself into a fetish. Finally, he was never interested in the mechanisms of Fordist labour subsumption, and is therefore irrelevant for a study of post-Fordist labour regimes.

The main Debordian idea that can add to our knowledge of digital work and labour is therefore to be found on the consumption side, more precisely in the mode of distribution. Owning the cheap means of production that suffice to extract value from his labour, self-exploiting himself mercilessly under the strict disciplines of the digital temporality of being logged-in (Huws, 2016), the digital worker also has to market himself (or herself). 'Free digital labour' has to advertise itself. The digital worker has to market his skills and his personality, in turn shaping the latter according to the needs of the market, turning his work and himself into a commodity and selling the package himself. This holds true both of the overwhelming majority of digital laborers who produce lines of code for one tiny segment of a large multinational project or actualize data, of platform workers who provide online and off-line services and depend on their ratings to find gigs, and also of more upscale knowledge workers.

The concept of digital artisan applies in this latter case, while perhaps not in the Barbrook and Schultz (1997) sense. Barbrook, while directly confronting the Californian ideology of the 'virtual class' (Barbrook and Cameron 1995), saw the group of highly skilled knowledge workers as 'the only subjects of history', able to 'transform the machines of domination into the technologies of liberation, a left-wing, European version of what Richard Florida (2002) was to call 'the creative class'. Barbrook and Schultz even planned to organize this class in a (stillborn) European Digital Artisans Network (EDAN). Barbrook hoped that this new class would 'rediscover the individual independence enjoyed by craftspeople during proto-industrialism, while promoting sociability 'within the highly collective institutions of the market and the state'.

When looking back on the lives of artisans/artists in the early years of capitalism - and here Benjamin Franklin's life provides an endless mine of 
information - one recognizes striking similarities: ownership of the means of production, complete control of and responsibility for the production process, subjection to market demands as a necessity for survival (with the essential role of credit and marketing platforms), the importance of networking to create a brand image (local respectability, membership in the churches and other associations, recognition and patronage from elite members, etc.). While Marx could construct the figure of the artisan in a somewhat mythical way from the evident contrasts in those departments with the condition of the emerging wage-worker (and that are to a great extent the conditions under which the overwhelming majority of digital workers operate today), the dialectic between autonomy and constraint looks very much the same, under different circumstances obviously. In both cases, the artisan is in charge of realizing both his exploitation (producing value to accumulate his capital, but also value that does not entirely accrue to him, because of the banker, the merchant, and the state, therefore maximizing the exercise of his labour power) and his alienation (partly disregarding his aesthetic tastes, constructing a market-friendly personality).

The great difference here that concerns us is that the knowledge worker as digital artisan cannot sell his labour power or the products he delivers (depending on the type of contract) without producing a spectacle of the merchandise he sells, since his works and himself must be displayed on the screens of potential buyers. This image is alien to him, not only because it is crafted for seduction and subject to the rules of the genre and the platforms, but because it comes to dominate him as an exterior force that makes him conform to it, analyse it, work to change it, in an endless quest for marketability. If the spectacle monopolized 'the majority of the time spent outside the production process' in the 1960s (SS 6), it is now part of the production process itself for digital artisans, in which they strive to produce and sell the spectacle of themselves, in an alienated process of production of subjectivities that is a negotiation between resistance to alienation and subjection to the market disciplines which have replaced Fordist labor disciplines.

This is exactly what Debord did for himself objectively, producing very little, either in terms of books or films, borrowing a lot from others, including enough to build a statue of himself that has endured, and marketing the package of his work and personality in a very efficient way, using all the communication marketing techniques imported from the USA: initially, Isidore Isou gave him access to the market for 'avant-garde products' under Isou's brand (he had to adopt the Letterist signature use of two first names, in this case Guy-Ernest); then he used the positioning strategy later conceptualized by Ries and Trout (Ries and Trout, 1981), constantly making a brand name for himself by opposing it to well-known brand names (Chaplin, Isou, Marx, Sartre, Breton, Trotsky, etc.); finally, when Debord had finally become a brand in its own right, he focused on the positioning away from competition strategy which was dear to his heart from the beginning but that he 
could not afford to implement completely in his early days. In the end, having lost both his main client, Lebovici, and his working capacity, he retreated to a market niche, his wife and remaining patrons. All in all, he was in a way a half-willing success in the 'society of the spectacle', and yet an enduring figure of rebelliousness against the 'non-life' that most people have to live, and a caller to action.

\section{Conclusion}

How can we explain the renewed interest in Debord in the 2010s, of which the present volume is yet another indicator? Globalization, and the globalization and 'democratization' of the Internet have made the spectacle of the commodity even more ubiquitous than in Debord's time. The sense of frustration among consumers, which needs to be reinforced perpetually to maintain demand, has been heightened by both the ubiquity of the spectacle and the change in temporalities that the speed of access to images, information and goods has created, fostering impatience. The ubiquity of machines (our computers are machines) and robots questions the notion of humanity itself. Among the reactions to the surfeit of spectacle and the collapse of time, environmentalists and others have pointed in the direction of a 'transition' towards a simpler and slower-paced life, reconnecting with the life vs the spectacle issue, and sometimes engaging in retreat. The latest international academic effort at 'reading Debord', at the end of 2016 (Lebras and Guy) was published in the aptly-named Frankenstein series of its French publisher, in the wake of books on Luddism in France, radical ecology, the dematerialization of books, and so on. A similar phenomenon of surfeit has affected the spectacle of politics, with the growth of disengagement, and so on. Turning to Debord for description is thus natural.

But none of this addresses the issue of human beings and mankind achieving the status of 'subjects of history', which was at the heart of Debord's quest. At base level, the choice of the word spectacle by Debord rests on an opposition between passive watchers and active players, which is useful, both in its aristocratic or democratic versions, and in the study of their interaction. As we have seen, he wrote very little about labour and labour processes, never engaged in large-scale organizing, and only made incantatory calls for the surrection of workers' councils. If we really want to do something against 'the spectacle of free labour' and unite with other workers so that we can all become active players, the central issue is organization. Organizing workers in the digital era is a practical task that requires from us academics both participation in organizing, since we are workers, and theoretical work to understand the specificities of the new labour regimes that have emerged and which call for the development of appropriate organization forms. 


\section{References}

Apostolidès, Jean-Marie. 2015. Debord le Naufrageur. Paris: Flammarion.

Apostolidès, Jean-Marie. 2015a. Debord le Naufrageur. Paris: Flammarion (e-PDF 9782081373532).

Barbrook, Richard, and Andy Cameron. 1995. 'The Californian Ideology'. Mute 1 (3). http://www.metamute.org/book/export/html/2281.

Barbrook, Richard, and Pit Schultz. 1997. The Digital Artisans Manifesto. http:// www.hrc.wmin.ac.uk/theory-digitalartisansmanifesto1.html.

Boorstin, Daniel. 1961. The Image, or What Happened to the American Dream. London: Weidenfeld and Nicolson.

Boorstin, Daniel. 1963. L'image ou ce qu'il advint du rêve américain. Paris: Julliard. Bourseiller, Christophe. 2016. Vie et mort de Guy Debord 1931-1994. Paris: Agora, ebook.

Chevalier, Louis. 1958. Classes laborieuses et classes dangereuses. Paris: Plon.

Debord, Guy. 1965. The Decline and Fall of the Spectacle-Commodity Economy. Unsigned tract originally translated into English by Donald-Nicholson Smith, distributed in the USA in December 1965, reprinted by Internationale Situationniste 10 (March 1966), translated by Ken Knabb, http://www. cddc.vt.edu/sionline/si/decline.html.

Debord, Guy. 1967. La Société du spectacle. Paris: Buchet-Chastel.

Debord, Guy. 1992a. La Société du spectacle. Paris: Champ Libre.

Debord, Guy. [1988] 1992b. Commentaires sur la Société du Spectacle. Paris: Champ Libre.

Debord, Guy. 1998. Des contrats. Paris: Le Temps qu'il fait.

Debord, Guy. 2005. Society of the Spectacle, translated by Ken Knapp. London: Rebel Press.

Florida, Richard. 2002. The Rise of the Creative Class: And How It's Transforming Work, Leisure, Community and Everyday Life. New York: Basic Books.

Fuchs, Christian. 2015. Reading Marx in the Information Age. New York: Routledge.

Gramsci, Antonio. 1977. 'Americanismo e Fordismo'. Quaderni del Carcere, ed. Valentino Gerratana. Turin: Giulio Einaudi, Vol. 3, 2138-2181.

Huws, Ursula. 2016. 'Logged Labour: A New Paradigm of Work Organisation?' Work Organisation, Labour and Globalisation, 10(1): 7-26.

Jappe, Anselm. [1993] 2001. Guy Debord. Paris: Denoël.

Lautréamont, 1938. Euvres complètes. Paris: Guy Lévis Mano.

Lebras, Laurence and Emmanuel Guy eds. 2016. Lire Debord. Paris: L'échappée, Collection Frankenstein.

Ries, Al and Jack Trout. 1981. Positioning: The Battle for Your Mind. New York: McGraw Hill.

Riesman, David, Nathan Glazer and Reuel Denney. 1950. The Lonely Crowd. New Haven, Connecticut: Yale University Press. 
Riesman, David, Nathan Glazer and Reuel Denney. 1964. La Foule solitaire. Paris: Arthaud.

Roszak, Theodore. 1968. The Making of a Counter Culture: Reflections on the Technocratic Society and Its Youthful Opposition. New York: Doubleday. Sanguinetti, Gianfranco. 2015. Argent, sexe et pouvoir : a propos d'une fausse biographie de Guy Debord. https://blogs.mediapart.fr/lechatetlasouris/ blog/150116/argent-sexe-et-pouvoir-propos-d-une-fausse-biographie-deguy-debord.

Whyte, William H. 1958. The Organization Man. New York: Simon \& Shuster.

Whyte, William H. 1959. L'Homme de l'organisation. Translated by Yves Rivière. Paris: Plon. 